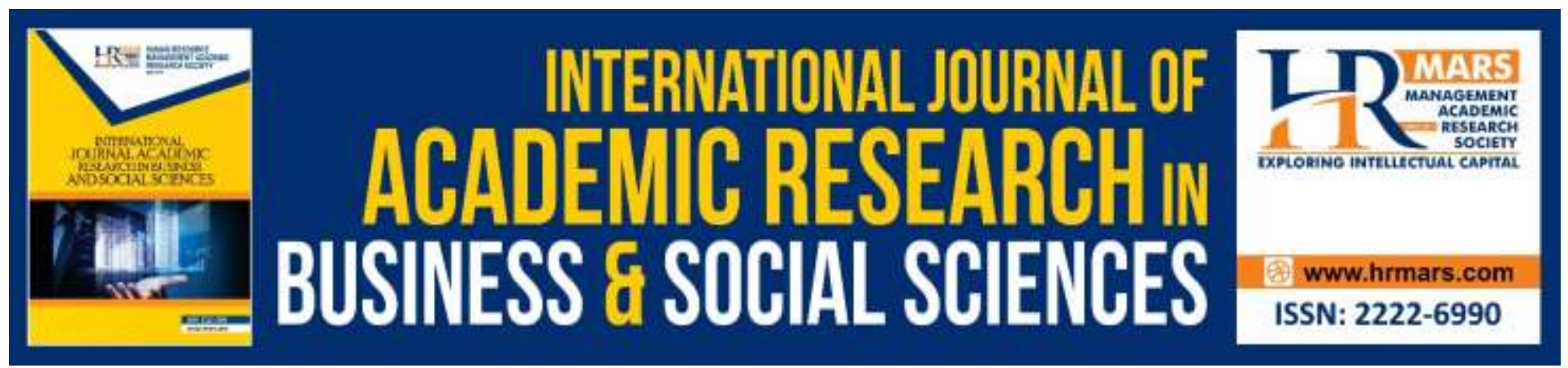

\title{
The Responsibility of The Muslim Concerning the Rules and Ethics of Visiting Al-Aqsa Mosque
}

Sharifah Norshah Bani Syed Bidin \& Ahmed S. A. Alqodsi

To Link this Article: http://dx.doi.org/10.6007/IJARBSS/v10-i4/7160 DOI:10.6007/IJARBSS/v10-i4/7160

Received: 02 February 2020, Revised: 22 March 2020, Accepted: 12 March 2020

Published Online: 12 April 2020

In-Text Citation: (Bidin \& AlQodsi, 2020)

To Cite this Article: Bidin, S. N. B. S., \& AlQodsi, A. S. A. (2020). The Responsibility of The Muslim Concerning the Rules and Ethics of Visiting Al-Aqsa Mosque. International Journal of Academic Research in Business and Social Science, 10(4), 621-626.

Copyright: (C) 2020 The Author(s)

Published by Human Resource Management Academic Research Society (www.hrmars.com)

This article is published under the Creative Commons Attribution (CC BY 4.0) license. Anyone may reproduce, distribute, translate and create derivative works of this article (for both commercial and non-commercial purposes), subject to full attribution to the original publication and authors. The full terms of this license may be seen

at: http://creativecommons.org/licences/by/4.0/legalcode

Vol. 10, No. 4, 2020, Pg. 621 - 626

http://hrmars.com/index.php/pages/detail/IJARBSS

JOURNAL HOMEPAGE

Full Terms \& Conditions of access and use can be found at http://hrmars.com/index.php/pages/detail/publication-ethics 


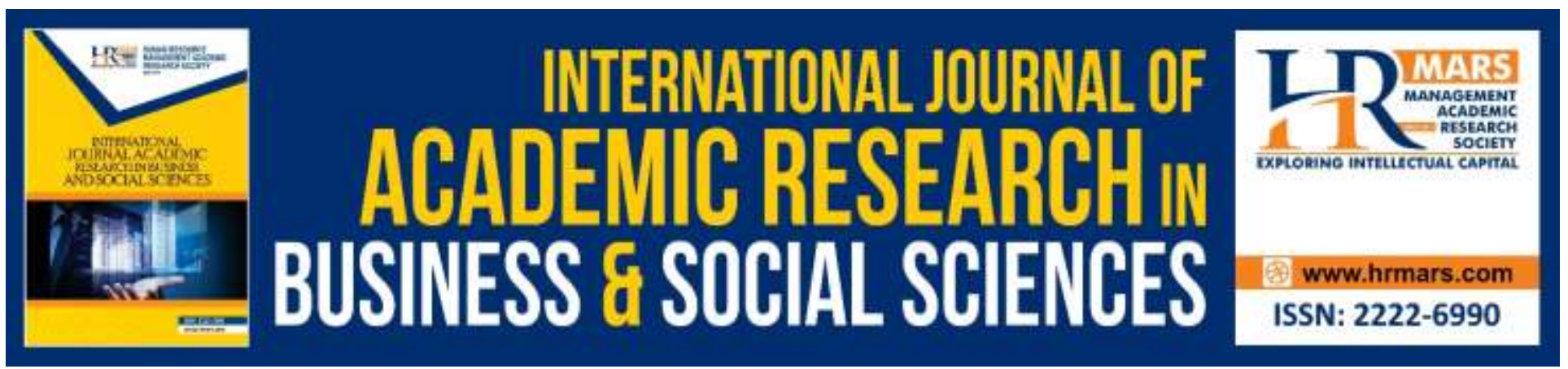

\title{
The Responsibility of The Muslim Concerning the Rules and Ethics of Visiting Al-Aqsa Mosque
}

\author{
Sharifah Norshah Bani Syed Bidin ${ }^{1} \&$ Ahmed S. A. alQodsi \\ ${ }^{1}$ Faculty of Islamic Contemporary Studies, Universiti Sultan Zainal Abidin Gong Badak Campus, \\ 21300 Kuala Nerus, Terengganu, Malaysia, ${ }^{2}$ University College Darul Quran Islamiah, 21200 Kuala \\ Terengganu, Malaysia \\ Email: sharifahns@unisza.edu.my
}

\begin{abstract}
Al-Aqsa Mosque in Islamicjerusalem (Baitul Maqdis) is the first of the two qibla (direction towards which muslims face during prayers) and the third of the other two holy mosques in Islam; ka'bah in Mecca and the prophet Muhammad PBUH mosque in Medina. It is also the ascension point of prophet Muhammad PBUH. But, it is unfortunate that some of the Muslim visitors ignored the ethics while entering and sitting in this noble mosque. This article discusses the Muslim responsibility towards al-Aqsa Mosque, to keep its sanctity while performing prayers there. This qualitative study focused on Islāmic ethics while visiting the mosque which based on the analysis of the verses of the al- Qur'an and Hadith Rasululllah PBUH. The study shows that there are many ethics that are compulsory to every muslim to know and practice it to maintain the prestige and respect of the alAqsa Mosque. Therefore, it will make sure that the ethics and worships of Muslims are practiced as stated in the al-Quran and al-Sunnah.
\end{abstract}

Keywords: Islamic Rules, Islamic Ethics, Al-Aqsa Mosque, Islamicjerusalem, Baitul Maqdis.

\section{Introduction}

Al-Aqsa Mosque has a great indepth into human history, it dated back to the beginning of creation on the earth. Al-Bukhari (2000) related from Abu Dharr (may Allah be pleased with him) that he said: $\mathrm{O}$ Messenger of Allah, which of the mosques was built first on the earth? He (the Prophet PBUH) replied: the Masjid al-Haram. He (Abu Dharr) said: then which one? He (the Prophet PBUH) replied: the Masjid al-Aqsa. I (Abu Dharr) asked: what is the interval between the two. He (the Prophet SAW) replied: forty years. It is clear from the previous narration that al-Aqsa Mosque is deeply rooted in time, it is very close to the period when the Masjid al-Haram was built. IbnHajar (1957), one of the great scholars, says: Prophet Adam (AS) was the one who built al-Aqsa Mosque.

Besides, al-Aqsa Mosque also has a great place in the Islam It is the first of the two Qibla, the third mosque, and the ascension point of the Prophet PBUH. For the greatest religious status of the 
INTERNATIONAL JOURNAL OF ACADEMIC RESEARCH IN BUSINESS AND SOCIAL SCIENCES

Vol. 10, No. 4, April, 2020, E-ISSN: 2222-6990 @ 2020 HRMARS

mosque, every muslim is compulsory to magnify the rules and ethics for entry, visit and I'tikaf (sitting in the mosque to perform a worship to Allah).

\section{The Rules and Ethics of Visiting Al-Aqsa Mosque}

Keeping Islāmic manners in the al-Aqsa Mosque is a manifestation of great honor to this holy mosque. It also can instill the nature of glorifying the masjidil aqsa and draw closer to Allah s.w.t. Here are some of the rules and ethics which are important to be enlighten to each muslim.

\section{First: Going to the Al-Aqsa Mosque in the Best Body and Using Good Scents}

Prayer is a link between the slave and his Lord. The worshiper stands in the front of Allah, pleading with Him, reciting al-Quran, remember Him, and pray to Him. So that, the worshiper must be in this great position on the best body. Hence the purity of the body and the garment. Also, the purification of the hadith and the dirts is a condition in the validity of the prayer, according to what is stated in the books of Hadith and Fiqh.

It is meant here to talk about the completeness of purity that every worshiper should have before entering the prayer, because many of the worshipers do not care about them nor give them attention. It is because some of the prayer turned from worship to habit, he comes to the mosque in the appearance less than the appearance when he goes by to the place of work. There are three things with regard to the good appearance, as below:

$\begin{aligned} \text { i. } & \text { External Appearance } \\ \text { ii. } & \text { Good Smell } \\ \text { iii. } & \text { Siwak }\end{aligned}$

The beautiful apparel, which is meant: the beauty of the clothes The worshiper should wear the best clothes of his Lord in all prayers, without distinguishing between the night prayer, the daytime prayer, the Fajr prayer and others. Because the dress is not meant to cover only the awrah, but it is intended to beautify the stand in the hands of the Lord of the Worlds. Allaah says (interpretation of the meaning): "O Children of Adam! wear your beautiful apparel at every time and place of prayer: eat and drink: But waste not by excess, for Allah loveth not the wasters” (al-A`raf, 7:31)

This verse is evidence that it is obligatory to cover the 'awrah by wearing clothes at every prayer. The clothes also show the blessings of God on his slaves; because of the cover of the nakedness, as well as adornment and beauty. This features only be fulfilled when the clothes were clean.

Ibn Katheer (1999)said in the interpretation of this verse: "And for this verse and what is mentioned in the meaning of the Sunnah, it is encouraged to be in a good beauty while going to do a prayer; because it is an adornment, as well as siwaak which is complete the beautiness .

'Abdullah bin Mas'ud (May Allah be pleased with him) reported: The Prophet(PBUH) said, 'He who has, in his heart, an ant's weight of arrogance will not enter Jannah."Someone said: " A man likes to 
INTERNATIONAL JOURNAL OF ACADEMIC RESEARCH IN BUSINESS AND SOCIAL SCIENCES

Vol. 10, No. 4, April, 2020, E-ISSN: 2222-6990 @ 2020 HRMARS

wear beautiful clothes and shoes?"Messenger of Allah PBUH said : "Allah is beautiful, He loves beauty. Arrogance means ridiculing and rejecting the Truth and despising people" (Muslim, n.d.).

The Muslim should feel the greatness of God who stands in front of Him and knows that he will be in the house of Allah. There is no doubt that standing in front of the Lord of the Worlds and visiting his house requires a good view and the splendor of the appearance. In addition, the meeting of his brothers worshipers and meet them in the mosque in a comfortable appearance and smell good, which helps to do a worship in a best condition.

\section{Paying Attention to Have A Good smell}

It is perfectly good body and beauty appearance that the worshiper is in a pleasant smell, away from all that has a foul smell, whether from the body itself or from external causes such as garlic, onions and leeks. Islam forbade who took any of that to attend the mosques; as it presence will harm the angels and other Muslims. The prevention of this public harm first to take into account from the interest of this person to go to the mosque. The Prophet PBUH said: "He who has eaten garlic or leek should not approach our mosque, because the angel are also offened by the strong smelss that offend the children of Adam"(Muslim, n.d.).

These are frank and true verses that show the concept of paying attention to have a good smell for those who wanted to attend mosques. The hadith shows that who eat garlic or onions or leeks is forbidden to join the isolation of Muslim mosques, and that he was ordered to sit at his home, a penalty for him missed the virtue of the group prayer, as he did not take into account the feeling of his brothers worshipers.

If this is the shar'i ruling on eating garlic, onions and leeks, which is permissible, then we also can measure the rule on smoking, which is haram by the Muslim scholar consensus. The smell of smoke considered under the general prohibition of attending the mosque for those who eat garlic, which is greater harm than eating garlic, which makes the worshipers harassed by the smoker who pray next to him in the queue. The prophet PBUH said : "Those who harm the Muslims in their ways, and they deserve to have to curse from them" If this is explanation about harming Muslims in their ways, means that those who harm them in the mosque is worse.

The Siwaak (Using Wooden Tooth Brush)

It is one of the supplements of purity, because the cleaning of the mouth from unpleasant odors. Islam has taken care of doing Siwaak to those who want to peform prayer, and the prophet PBUH encourage it by word and action. The Prophet PBUH said that: "A siwaak is a disinfectant for the mouth, and it is pleasing to the Lord"(al-Nasaie,1986). A disinfectant of the mouth, because it is the best way to clean teeth and mouth.

\section{Second : Prefer the Right Foot While Entering the Al-Aqsa Mosque}

There is a special attribute to enter the al-Aqsa Mosque i.e prefer the right foot while entering. It is because the right shows the honor toward mosque. Many visitors did not practice this attribute for the reason of ignorance or were in hurry. Hadith that was narrated from Anas - may Allah be pleased 
INTERNATIONAL JOURNAL OF ACADEMIC RESEARCH IN BUSINESS AND SOCIAL SCIENCES

Vol. 10, No. 4, April, 2020, E-ISSN: 2222-6990 @ 2020 HRMARS

with him - that he said: (It is sunnah if you enter the mosque to start your right foot, and if you go out to start your left foot) (al-Hakim, 1990).

\section{Third : Praying Upon Entering and Leaving the Al-Aqsa Mosque}

As the al-Aqsa Mosque is the loved place by Allah for, they are places of obedience, the descent of mercy which its basis on piety, where God worship and unite, the Prophet PBUH has guided who come to the mosque to make prayers right to the situation. Prophet PBUH said: "If one of you entered the mosque, he has to say: "O God, open to me the doors of your mercy", and if he goes out, let him say: "O God, I ask you please ".

\section{Fourth : Greeting Prayer to The Mosque (Salat Tahiyyat al-Masjid)}

One of the etiquettes of attending mosques - the places of worship - is to pray two rak'ahs in the interior in order to honor Allah, and in honor of the place of worship. This prayer is a greeting to the mosque, because one who enter the mosque begins with them as he begins to greet the people when meeting them. The Prophet PBUH said: "When anyone among you enters the mosque, he should not sit till he has observed two rak'ahs" (Muslim,n.d.) . Majority of Muslim scholars said that it is sunnah to make a greeting prayer to the mosque, but it is not obligatory. Al-Nawawi (1970) said: "It is the consensus of the Muslims".

\section{Firth: Choose to Sit at The First Row (Saf)}

Some of the ethics of attending mosques: step forward to the first row, and proximity to the imam, for the first row will meet the great reward. It was narrated from 'Irbad bin Sariyah that the Messenger of Allah PBUH used to ask for forgiveness for the first row three times and for the second row twice (IbnMajah,n.d). This hadith indicates the virtue of the first row, and that it should be concern by every Muslim to come to the mosque earlier.

\section{Sixth : Stay Away from Stepping Over the People in The Mosque}

Stepping the worshipers' necks and raise the legs above their heads are considered disturbing them, although to complete with the rows, especially in the al-Aqsa Mosque, which is frequented by worshipers. The Prophet PBUH forbade stepping over the people. Abu al-Zahiriyyah said: We were in the company of 'Abd Allah b. Busr, the Companian of the Prophet PBUH, on a Friday. A man came and stepped over the people while the Prophet was giving the sermon on Friday. The Prophet PBUH said: Sit down, you have annoyed (the people) (AbuDawud, 2009). This hadith is one of the strongest of what is mentioned in about the prohibition of stepping over the people.

\section{Seventh: Stay Away from Begging Inside the Mosque}

Mosques are the houses of Allah, built for remembrance, prayer and worship towards Him. The mosques are not suitable for begging and collecting money, as it will annoy the worshipers. The prohibition on asking for charity in the mosque is very clear; it is an affirmation of the sanctity of the mosque and deterring weak people from taking the mosque as a place to gain money, especially there are many liars with many tricks in collecting money for their personal interest. 
INTERNATIONAL JOURNAL OF ACADEMIC RESEARCH IN BUSINESS AND SOCIAL SCIENCES

Vol. 10, No. 4, April, 2020, E-ISSN: 2222-6990 @ 2020 HRMARS

\section{Conclusion}

In short, there is a group of rulings and religious ethics of keeping the Masjid al-Aqsa. It is thus imperative on us to guide and follow them in order to respect the importance and holiness of the alAqsa Mosque, for it occupies the high place in our great Islāmic religion. Hence, it will inculcate the love of al-Aqsa mosque into the mind of every Muslim especially the new generation

\section{Acknowledgement}

This article is extracted from the Special Research Grant Scheme. Reference number: UniSZA/SRGS$\mathrm{FKI} / 2018 / 03$ Special thanks go to the Research Management, Innovation and Commercialization Centre (RMIC), Universiti Sultan Zainal Abidin for the funding.

\section{Corresponding Author}

Sharifah Norshah Bani Syed Bidin, Ph.D

Faculty of Islamic Contemporary Studies, Universiti Sultan Zainal Abidin, Kampus Gong Badak, 21300 Kuala Nerus, Terengganu, Malaysia.

Email: sharifahns@unisza.edu.my

\section{References}

Al-Quran

AbuDawud, S. A. (2009). Sunan Abi Dawud. Cairo: Dar al-Risalah al-Islamiyyah.

Al-Bukhari, M. I. (2000). Sahih al-Bukhari. Beirut : Dar Tauq al-Najat.

Al-Hakim, A. A. A. (1990). Al-Mustadrak `Ala al-Sahihayn. Beirut: Dar al-Kutub al-'Ilmiyyah.

Al-'Asqalani, I. H. (1957). Fath al-Bari Sharh Sahih al-Bukhari. Beirut: Dar al-Ma`rifah.

IbnKatheer, I. U. (1990). Tafsir al-Quran al- 'Azim. Cairo: Dar Taibah.

IbnMajah, M. Y. (n.d.). Sunan Ibn Majah. Cairo: Dar Ihya' al-Kutub al-'Arabiyyah.

Muslim, H. (n.d).Sahih Muslim. Beirut : Dar Ihya' al-Turath.

Al-Nasaie, A. S. (1999). Sunan al-Nasaie. Halab: Maktab al-Mabu`at al-Islamiyyah.

Al-Nawawi, M. D. Y. (1970). Al-Minhaj Sharh Sahih Muslim bin al-Hajjaj. Beirut: Dar Ihya' al-Turath https://sunnah.com/ Retrieved Mac 03,2020. http://www.surah.my/?|=en Retrieved Mac 03,2020. 